\title{
Protein, Fat, Calories, Minerals, Phytic acid and Phenolic In Some Plant Foods Based Diet
}

\section{Ali Aberoumand*}

Department of Fisheries, Behbahan High educational Complex, Behbahan, Iran

\begin{abstract}
The most important nutrients present in plants are: carbohydrates, such as the starch and free sugars, oils, proteins, minerals, ascorbic acid, and the antioxidant phenols. The Plants Alocacia indica Sch.,Asparagus officinalis DC., Chlorophytum comosum Linn., Cordia myxa Roxb., Eulophia ochreata Lindl., Momordica dioicia Roxb., Portulaca oleracia Linn. and Solanum indicum Linn. are widely wild in many regions of Iran and India. Association of the Official Analytical Chemists and Folin-Ciocalteau micro method are used for nutritional analysis of the plants. Results indicated that Portulaca oleracia Linn. and Asparagus officinalis DC. contain high amounts of proteins, fats and calorie values. These plants are consumpted as vegetables in Iran people diets.
\end{abstract}

Keywords: Nutritional values, Edible plants, Portulaca oleracia, Asparagus officinalis

\section{Introduction}

Fruits are important sources of minerals, fiber and vitamins, which provides essential nutrients for the human health. In addition, it is known that some fruits have the so-called 'anti-nutritional' factors (e.g. phytic acid and tannins) that can diminish the nutrient bioavailability, especially if they are present at high levels [1], Nevertheless, it has been reported that these anti-nutritional factors could help to prevent and treat several important diseases; remarkably, the anti-carcinogenic activity of phytic acid has been demonstrated by in vitro and in vivo assays. The most important nutrients present in plants are: carbohydrates, such as the starch and free sugars, oils, proteins, minerals, ascorbic acid, and the antioxidant phenols, such as chlorogenic acid and its polymers. These molecules are involved in pathogen resistance in plants, and the chlorogenic acid concentration represents about the $90 \%$ of the total phenolic compounds in plants $[2,3]$.

Protein malnutrition is a major public health problem in the developing world. The major food crops being roots and tubers hence the diets in these parts are predominantly starchy. The trace elements, together with other essential nutrients, are necessary for growth, normal physiological functioning, and maintaining of life; they must be supplied by food, since the body cannot synthesis them. The exact classification of trace versus macro minerals is not clear cut, but traces are often considered as minerals required by the body in amounts less than $100 \mathrm{mg}$ daily. While some of them are vitally important for health, the roles of others are unclear. Recommended intakes have been set for some trace elements and their deficiency can lead to disease, but a lack of others does not cause any recognized problems. To decide whether a micro-nutrient is "essential" or not, several criteria are used, such as the presence of the nutrient in healthy tissue, if it appears in the fetus and newborns and if the body maintains homeostatic control over its uptake in the bloodstream or tissue and its excretion $[4,5]$.

Plants, which are sources of phytochemicals with strong antioxidant activity, have attracted a great deal of attention in recent years. Antioxidants, which inhibit the oxidation of organic molecules, are very important, not only for food preservation, but also for the defense of living systems against oxidative stress [6]. Phenolic antioxidants interrupt the propagation of the free radical autoxidation chain by contributing a hydrogen atom from a phenolic hydroxyl group, with the formation of a relatively stable free radical that does not initiate or propagate further oxidation processes $[7,8]$.

Dietary fiber (DF) plays an important role in decreasing the risks of many disorders such as constipation, diabetes, cardiovascular diseases (CVD), diverticulosis and obesity (Spiller, 2001). Plant foods are the only sources of DF. All the fractions (cellulose, lignin, hemi cellulose, pectin, gums and mucilage) of DF are the major constituents of plant cell wall [8]. Indian diets predominantly consist of a variety of plant foods such as cereals, pulses, green leafy vegetables (GLV), roots, tubers, other vegetables, fruits, oil seeds, spices and condiments. Fruits are consumed in various forms like fresh, dried, frozen or canned. The polysaccharides comprising a major part of DF in fruits and vegetables are beneficial to healthy human volunteers, since the consumption of fiber lowers plasma cholesterol levels $[9,10]$.reported protective effect of fruits and vegetables against the development of stroke in men. Addition of fruits and vegetables to the regular diet of infracted survivors resulted in a decreased mortality and subsequent infarctions. Therefore, the dietary fiber may play a major role in determining the health and disease conditions of different population groups.

Inositol hexakisphosphate ( $\operatorname{Ins}_{6}$ ), commonly known as phytate, is a major component of plant storage organs such as seeds, roots and tubers, where it serves as a phosphate source for germination and growth [11]. Due to its ability to chelate and precipitate minerals, phytate can decrease the bioavailability of critical nutrients such as zinc, iron, calcium and magnesium in foods such as whole grains, nuts and legumes [12], At the same time, phytate may have beneficial roles as an antioxidant, ant carcinogen and more [13]. Aim of this study is preliminarily study on nutritional values of new food plants obtained from India and Iran.

Corresponding author: Ali Aberoumand, Department of Fisheries, Behbahan High educational Complex, Behbahan, Iran, Tel: 0098-0916-671-6540; Fax: 0098612322242; E-mail: aaberoomand@yahoo.com

Received September 06, 2010; Accepted December 01, 2010; Published May 01, 2011

Citation: Aberoumand A (2011) Protein, Fat, Calories, Minerals, Phytic acid and Phenolic In Some Plant Foods Based Diet. J Food Process Technol 2:114 doi:10.4172/2157-7110.1000114

Copyright: $\odot 2011$ Aberoumand A. This is an open-access article distributed under the terms of the Creative Commons Attribution License, which permits unrestricted use, distribution, and reproduction in any medium, provided the original author and source are credited. 


\section{Material and Methods}

\section{Sample preparation}

Selected wild edible plants were collected from various localities of Maharashtra (India) and Iran. Three wild edible plants were collected from India viz Alocacia indica, Momordica dioica and Eulophia ochreata in September 2007. Five wild edible plants were collected from Iran viz Asparagus officinalis, Chlorophytum comosum, Codia myxa, Portulaca oleracia and Solanum indicum were collected from Iran in October 2007. Healthy and disease free edible plant part/s selected and dried them under shade so as to prevent the decomposition of chemical compounds present in them. All the dried material powdered in blander for further study.

\section{Proximate composition}

Ash and fat contents were assayed by the Association of the Official Analytical Chemists (AOAC, 1984) Methods 14004, 14009 and 14006, respectively. Nitrogen was determined using the Kjeldahl method (Matissek, R., Schnepel, F.M. \& Steiner, G. (1989) The quantity of protein was calculated as $6.25 \times \mathrm{N}$.

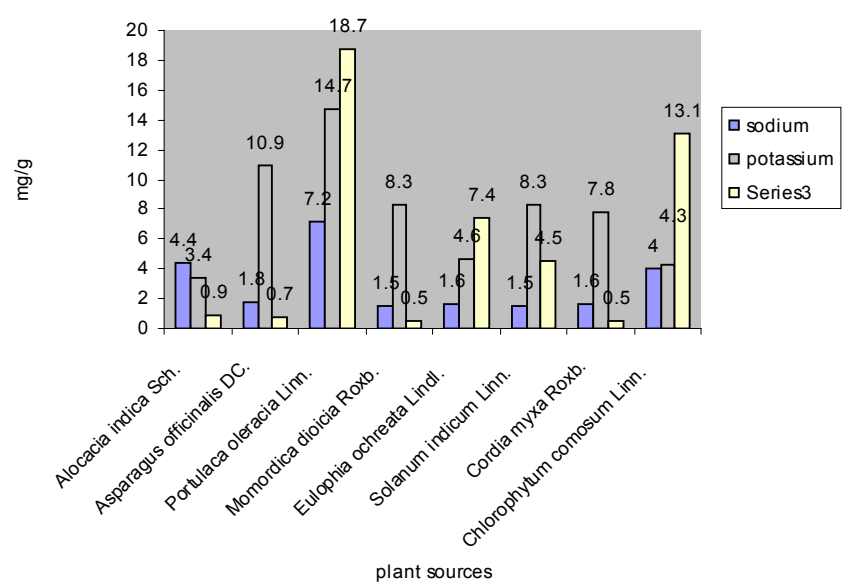

Figure 1: Amounts of macro elements of edible plants each value is the mean of three determinations.

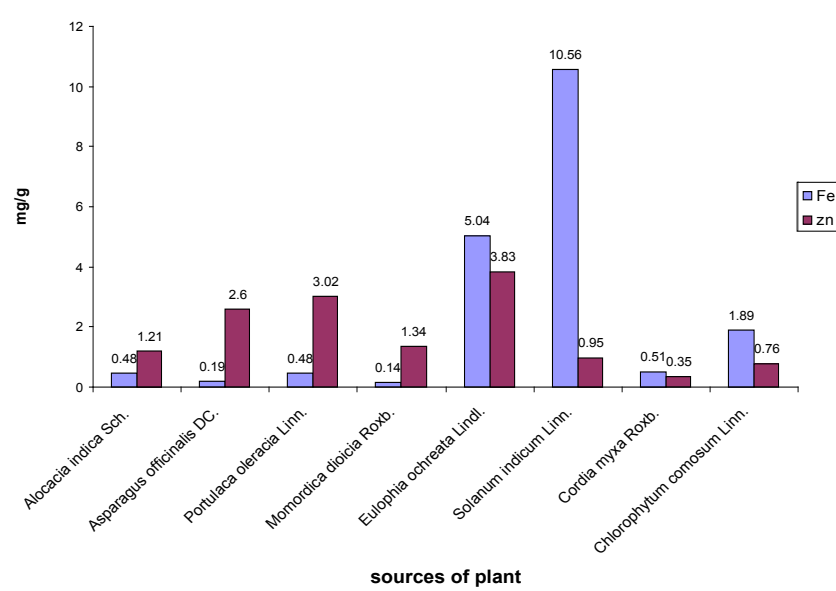

Figure 2: Amounts of micro elements of edible plants each value is the mean of three determinations.

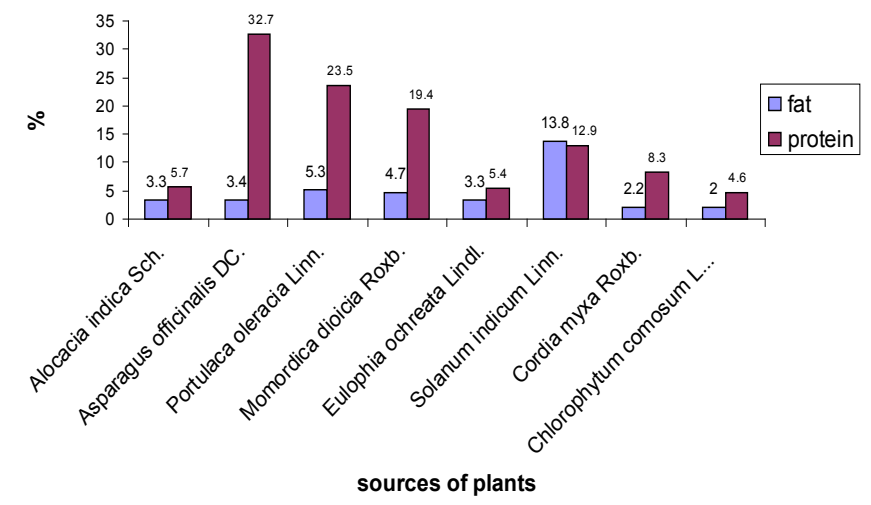

Figure 3: Values of protein and fat of edible plants each value is the mean of three determinations.

\section{Mineral content}

Mineral content was analyzed with a Perkin-Elmer (optima) 3000 DV analyzer with induction coupled plasma atomic emission spectroscopy (ICPAES, (Eknayake et al, 1999). The sample (2 g) was digested with $20 \mathrm{ml}$. concentrated nitric acid (BDH-Aristar) until a transparent solution was obtained. The instrument was calibrated with known standards and samples analyzed at corresponding wavelengths. Five-point standard curves were made for all analyzed minerals using reference materials. Linear regression analysis of the standard curves indicated they were linear with correlation coefficients in the range of 0.997-0.999. Selenium was determined as hydride using a hydride generator (VGA-76). The samples digested in $\mathrm{HNO}_{3}$ were mixed with concentrated $\mathrm{HCl}$ and heated to 70 to $90^{\circ} \mathrm{C}$ for $10 \mathrm{~min}$ and cooled before injection into hydride generator followed by $\mathrm{NaBH} 4$.

\section{Determination of phytate content}

The phytate content was determined by the method of (14), based on the ability of standard ferric chloride to precipitate phytate in dilute $\mathrm{HCl}$ extracts of the vegetables.

\section{Determination of total phenolic compounds}

Total phenols were extracted by heating a weighed portion (50$500 \mathrm{mg}$ ) of dried sample with $5 \mathrm{ml}$ of $1.2 \mathrm{M} \mathrm{HCl}$ in $50 \%$ aqueous methanol for $2 \mathrm{hr}$. at $90^{\circ} \mathrm{C}$ and analyzed by Folin-Ciocalteau micro method [15], Results were expressed as mg of gallic acid per $100 \mathrm{~g}$ of dried plant material.

\section{Determination of calorie}

Total calorie value is equal with fat calorie + protein calorie + sugars calorie. Each gram fat give $9 \mathrm{kcal}$, each gram protein give $4 \mathrm{kcal}$ and each gram sugar give $4 \mathrm{kcal}$.

\section{Results and Discussion}

Many studies have been done by various research workers all over the world by selecting one or more plants particularly leaves, fruits, roots, stem, food plants and so on but rarely by selecting a particular family. In this investigation works pertaining to seven different families (Araceae, Liliaceae, Boraginaceae, Orchidaceae, Cucurbitaceae, Portulacaceae and Solanaceae) are selected.

The results of proximate composition of the edible plants have been shown in Figure 3. The ash content, which is an index of mineral contents, for the edible plants the value of 10.7 in per cent DW was less 
than to the values for other edible leaves such as Momordica balsamina leaves $(18.00 \pm 1.27$ per cent DW) $[15,16]$. It is apparent that Cordia myxa fruit was a good source of potassium, Chlorophytum comosum root tubers was a good source of sodium and potassium. Portulaca oleracia leaves and stem was a good source of sodium, potassium, calcium and zinc, S. indicum leaves was a good source of mineral elements, Eulophia ochreata tubers was a good source of potassium, calcium, iron and zinc, Momordica dioicia fruit was a good source of potassium, and zinc, $A$. officinalis stem was a good source of trace elements especially $\mathrm{Zn}$ and Alocacia indica stem was a good source of sodium, potassium, and zinc. The crude protein contents of Cordia myxa fruit, Alocacia indica stem, Eulophia ochreata tubers and Chlorophytum comosum root tubers was lower than what is reported for some lesser known wild leafy vegetables

\section{Values of total phytic acids and total phenolic compounds of edible plants}

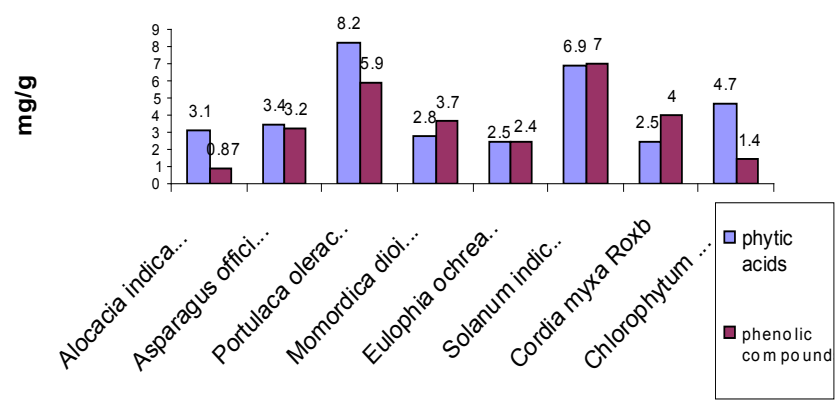

Figure 4: Values of total phytic acids and total phenolic compounds of edible plants each value is the mean of three determinations.

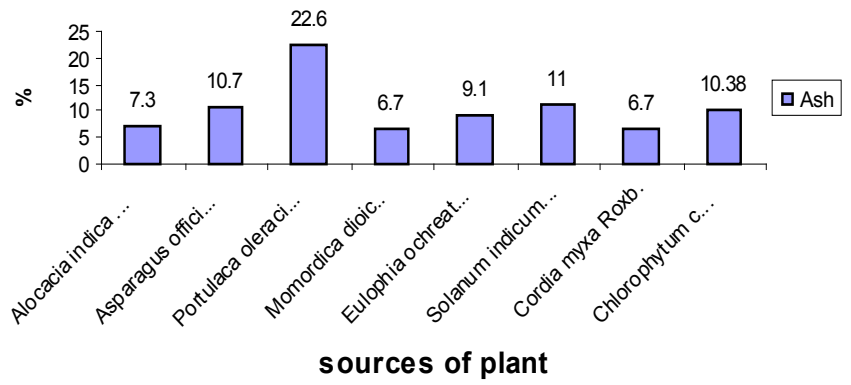

Figure 5: Amounts of total ash of edible plants each value is the mean of three determinations.
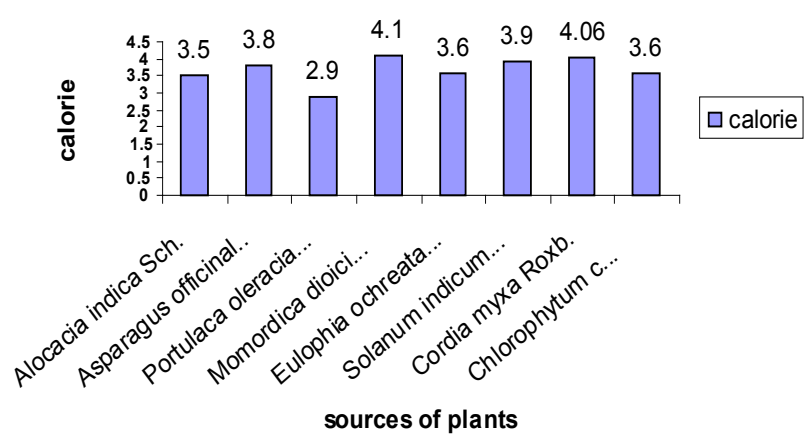

Figure 6: Values calories of edible plants each value is the mean of three determinations.

\begin{tabular}{|c|c|c|c|c|}
\hline \multirow{2}{*}{ Mineral } & \multicolumn{4}{|c|}{ Recommended Dietary Allowances(mg/day) } \\
\hline & Children & Adult male & Adult female & Pregnant \& \\
\hline & \multicolumn{2}{|c|}{$7-10$ Years } & \multicolumn{2}{c|}{ Lactating mother } \\
\hline Potassium & 800 & 800 & 800 & 1200 \\
\hline Calcium & 1600 & 2000 & 2000 & 2000 \\
\hline Sodium & 400 & 500 & 400 & 500 \\
\hline Iran & 10 & 10 & 15 & 13 \\
\hline Zinc & 10 & 15 & 12 & 19 \\
\hline
\end{tabular}

*The data are mean values $\underline{ \pm}$ deviation(SD) of three replicates

Table1: Mineral composition of Recommended Dietary Allowances(mg/day).

such as Momordica balsamina (11.29 \pm 0.07 iper cent), [17,18].Food plants that provide more than $12 \%$ of their calorific value from protein are a good source of protein. In that context, these edible plants are a relatively good source of protein [17]. The crude lipid contents of all edible plants except Solanum indicum leaves were less than the range (8.3 - 27.0 in per cent DW) reported for some vegetables consumed in Nigeria and Republic of Niger [18]. All edible plants contain comparable amount of carbohydrate for Momordica balsamina (39.05 \pm 2.01 per cent) [18]. The crude fibre contents of all edible plants were higher than the reported values $(8.50-20.90$ per cent) for some Nigeria vegetables [17]. One discussed drawback to the use of vegetables in human nutrition is their high fibre content, which may cause intestinal irritation and a decrease of nutrient bioavailability [17].The fibre RDA values for children, adults, pregnant and breast-feeding mothers are $19-25,21-38,28$ and 29 in per cent respectively. Thus, all edible plants could be a valuable source of dietary fibre in human nutrition. The lowest of calorific value was estimated to be $281.4 \mathrm{kcal} / 100 \mathrm{~g}$ (DW), which is an indication that it could be an important source of dietary calorie. High calorific content of the fruit or vegetable could be attributed to high lipid content.

\section{Mineral content}

Figure 1, Figure 2 and Figure 5 shows the results of the mineral concentrations of edible plants. Nutritional significant of some elements is not compared with the standard recommended dietary allowance. When compared with standard values as showed in Table 1, some edible plants less than adequate level of $\mathrm{K}, \mathrm{Fe}, \mathrm{Zn}, \mathrm{Ca}$, and $\mathrm{Na}$, but the plant fruit could be good sources of some elements.

Momordica (4125/83Kcal/Kg) and Cordia (4067/94 Kcal/Kg) have maximum calorie values and Portulaca $(2913 / 82 \mathrm{Kcal} / \mathrm{Kg})$ has minimum calorie value and the others samples have medium calorie values $(3514 / 4 \mathrm{Kcal} / \mathrm{Kg}$ to $3647 / 23 \mathrm{Kcal} / \mathrm{Kg}$ ) (Figure 6).

It is observed Portulaca oleracia Linn. with $823.6 \mathrm{mg} / 100 \mathrm{~g}$ has maximum value and then solanum indicum with $695.8 \mathrm{mg} / 100 \mathrm{~g}$ has high value and Eulophia with $255.6 \mathrm{mg} / 100 \mathrm{~g}$ has minimum value and the others plants have less than medium values from phytic acid content point of view (Figure 4) and also Solanum indicum Linn. with $7.02 \mathrm{mg} / \mathrm{g}$ has maximum phenolic compounds value and then Portulaca oleracia Linn. with $5.86 \mathrm{mg} / \mathrm{g}$ have high phenolic compounds. Alocacia indica Sch. with $0.87 \mathrm{mg} / \mathrm{g}$ has minimum phenolic compounds value. Cordia Myxa Roxb with $4.02 \mathrm{mg} / \mathrm{g}$ and Momordica dioicia Roxb. with $3.69 \mathrm{mg} / \mathrm{g}$ and Asparagus officinalis DC. with $3.17 \mathrm{mg} / \mathrm{g}$ have medium phenolic compounds value (Figure 4).

\section{Acknowledgements}

Author is grateful to the Head Department of Botany University of Pune for providing necessary laboratory facilities and for encouragement. Author is thankful to Head Department of Food Science Technology of Ramin Agricultural University of Iran. 
Citation: Aberoumand A (2011) Protein, Fat, Calories, Minerals, Phytic acid and Phenolic In Some Plant Foods Based Diet. J Food Process Technol 2:114. doi:10.4172/2157-7110.1000114

Page 4 of 4

\section{References}

1. Edmonds J, Chweya J (1995) Black nightshades, Solanum nigrum L and related species. Promoting the conservation and use of underutilized and neglected crops., Taylor \& Francis, London.

2. Burlingame B (2000) Comparison of total lipids, fatty acids, sugars and nonvolatile organic acids in nuts from Castanea species. Journal of Food composition and Analytical 13: 99-100.

3. Nesamvuni C, Steyn N, Potgieter M (2001) nutrients analysis of selected western African foods. South Afr J Food Sci 97: 51-54.

4. Sena L, VanderJagt D, Rivera C, Tsin A, Muhammadu I (1998) Nutritional profile of some edible plants from Mexico. Plant Foods for Human Nutrition 52: $17-30$.

5. Abuye C, Urga K, Knapp H, Selmar D, Omwega A (2003) A survey of wild, green, leafy vegetables and their potential in combating micronutrien deficiencies in rural populations. East African Medicine Journal 80: 247-252.

6. AOAC (1990) Official methods of analysis, 14th edition, Association of Official Analytical Chemists, Washington DC, Arlington, Virginia, USA.

7. Vadivel V, Janardhanan, K (1999) Analysis of nutritional components of eight famine foods of the Republic of Niger. Plant Foods for Human Nutrition 55: 369-381

8. Funtua I, Trace J (1999) Quantitative variability in Pisum seed globulins: its assessment and significance. Plant Foods for Human Nutrition 17: 293-297.

9. Funtua I (2004) Minerals in foods: Dietary sources, chemical forms, interactions, bioavailability. Instrumentation Science and Technology 32 : 529-536.
10. Ifon E, Bassir O (1980) Determination of carbohydrates in foods. II -unavailable carbohydrates. Food Chemistry 5: 231-235.

11. Lockeett C, Calvert, C, Grivetti L (2000) Quantitative and Qualitative variability of pea (Pisum sativum L.) protein composition. International Journal of Food Science and Nutrition 51: 195-208.

12. Isong $E$, Idiong $U$ (1997) Nutrient content of the edible leaves of seven wild plants from Nigeria. Plant Foods for Human Nutrition 51: 79-84.

13. Pearson D (1999) Nutrient and chemical composition of 13 wild plant foods of Nigeria, Ghana. Journal of Food Science 39: 91- 92.

14. Faruq U, Sani A, Hassan L (2002) Composition and distribution of deadly nightshade. Nigeria Journal of Basic Application and Science 11: 157-164.

15. Asibey-Berko E, Tayie F (1999) The antibacterial properties of some plants found in Hawaii, Ghana Journal of Food Science 39: 91-92.

16. Aletor V, Adeogun O (1995) Chemical analysis of the fruit of Vitex doniana (Verbenaceae). Food Chemistry 53: 375-379.

17. Plessi M, Bertelli D, Phonzani A, Simonetti M, Neri A (1999) Role of indigenous leafy vegetables in combating hunger and malnutrition. Journal of Food Composition and Analytical 12: 91-96.

18. Food and Nutrition Board (2001) Institute of Medicine. National Academy of Sciences. Dietary Reference Intake: Elements. National Academy Press, Washington D.C. USA. 